\begin{tabular}{|l|l|l|l|l|l|}
\hline MUNIBE Antropologia-Arkeologia & $n^{\circ} 72$ & $157-170$ & DONOSTIA & 2021 & ISSN 1132-2217 • eISSN 2172-4555 \\
\hline
\end{tabular}

\title{
Iron Age craftworks in the southeast of the Iberian Peninsula. An approach based in Cultural Inheritance Theory
}

\author{
Artesanías de la Edad del Hierro en el sureste de la Península Ibérica. \\ Una aproximación basada en la Teoría de la Herencia Cultural
}

KEY WORDS: Transmission of cultural knowledge, ivory combs, perforated plates, craftspeople, Iberian culture.

PALABRAS CLAVES: Transmisión cultural del conocimiento, peines de marfil, placas perforadas, artesanos, Cultura Ibérica. GAKO-HITZAK: Ezagutzaren transmisio kulturala, marfilezko orraziak, zulatutako plakak, artisauak, iberiar kultura.

\section{Consuelo MATA PARREÑO(1), Lucía SORIA COMBADIERA(2), Marta BLASCO MARTíN(3), Elena MORA GARCíA ${ }^{(4)}$, Mercedes FUENTES ALBERO(5), Joan BERNABEU AUBAN( ${ }^{(6)}$}

\section{ABSTRACT}

The aim of this paper is to examine the craftwork on hard materials of animal origin from the Iron Age of the southeast of the Iberian Peninsula. We deal with the processes of craftsmanship, transmission of knowledge and the circulation of ivory combs and perforated bone plates. The Cultural Inheritance Theory offers a framework to help identify social dynamics in the craft productions and the transmission of the cultural knowledge between and among individuals (vertical, horizontal or oblique). Therefore, the consequences of these cultural transmission processes will be different for each artefact. This could be used to investigate relative levels of standardization within and between groups.

For this we use various morphometric measurements related to the technological process of making combs and perforated plates. The results point to an oblique transmission with particularities linked to each object related to their formal and decorative characteristics and owing to their raw materials.

\section{RESUMEN}

El objetivo de este artículo es examinar la artesanía sobre materias duras de origen animal de la Edad del Hierro en el sureste la Península Ibérica. Trataremos los procesos de artesanía, transmisión de conocimientos y circulación de peines de marfil y placas perforadas de hueso. La Teoría de la Herencia Cultural ofrece un marco teórico para ayudar en la identificación de la dinámica social de la producción artesanal y las formas de transmisión del conocimiento cultural (vertical, horizontal u oblicua). Por tanto, las consecuencias de estos procesos de transmisión cultural serán diferentes para cada artefacto. Esto puede utilizarse, también, para investigar los niveles relativos de estandarización dentro y entre grupos. Para ello utilizamos varias medidas morfométricas relacionadas con el proceso tecnológico de elaboración de peines y placas perforadas. Los resultados apuntan a una transmisión oblicua con particularidades ligadas a cada objeto, relacionadas con sus características formales y decorativas y sus materias primas.

\section{LABURPENA}

Artikulu honen helburua da iberiar penintsulako hego-ekialdeko Burdin Aroko animalia-jatorriko materia gogorrekin egindako artisautza aztertzea. Artisautza-prozesuak, ezagutzen transmisioa eta marfilezko orrazien eta hezurrezko zulatutako plaken zirkulazioa izango ditugu hizpide. Herentzia Kulturalaren Teoriak artisautzako produkzioaren dinamika soziala eta ezagutza kulturala transmititzeko formen (bertikala, horizontala edo zeiharra) identifikaziorako lagungarri den testuinguru teorikoa eskaintzen du. Horrenbestez, transmisio kulturaleko prozesu horien ondorioak ezberdinak izango dira artefaktu bakoitzerako. Hori guztia talde baitan eta taldeen artean estandarizazioko maila erlatiboak ikertzeko ere erabil daiteke. Horretarako, orraziak eta zulatutako plakak prestatzeko prozesu teknologikoarekin lotutako neurri morfometriko batzuk erabili ditugu. Emaitzek agerian utzi dute lehengaiekin, ezaugarri formalekin eta apaingarriekin lotutako eta objektu bakoitzari lotutako berezitasunak dituen transmisio zeiharra gertatu dela.

\footnotetext{
(1) GIUV2015-222 GRAM, Dept. Prehistòria, Arqueologia i Història Antiga, Universitat de València, Av. Blasco Ibáñez 28, 46010 Spain. Phone: +34963864070. consuelo.mata@uv.es.

(2) ARQPAT (Arqueología y Patrimonio), Departamento de Historia, Universidad de Castilla-La Mancha.

(3) GIUV2015-222 GRAM, Dept. Prehistòria, Arqueologia i Història Antiga, Universitat de València.

(4) Independent researcher.

(5) Independent researcher

(6) GIUV2015-213 PREMEDOC, Dept. Prehistòria, Arqueologia i Història Antiga, Universitat de València.
} 


\section{INTRODUCTION}

The Iron Age societies that developed in the eastern façade of Iberia are currently known as the Iberian Culture. Iberian Culture spans from the sixth century BC to the Roman conquest. Iberians developed a high level of urbanization, complex and complementary economic strategies (agricultural practice, metallurgy, livestock breeding, writing, systems of weights and measurements, etc.) and religious beliefs, varying scales of trade and exchange, standardized funerary rituals, social stratification and independent socio-political territories (Ruiz-Rodríguez and Molinos, 1998; Bonet and Mata, 2014; Grau and Vives-Ferrándiz, 2018; Grau and Rueda 2018).

Although there have been some attempts to identify specialized crafts (Mata-Parreño and Pérez-Jordà, 2000; Mercadal, 2005), little research has been conducted on the hard animal products manufactured by the Iberian people. In fact, these kinds of craftworks had been made invisible by archaeological research, which has tended to privilege other classes of objects more common in the Iberian sites. These objects, however, are found all over Iberian sites, as ornaments and utilitarian objects that would form part of daily activities and/ or symbolic practices (Blasco Martín, 2020).

The present work explores new approaches to technological practices and their transmission, drawing on the analysis of two different sets of objects elaborated using these raw materials: ivory combs and perforated bone plates. Based on the raw material, the combs are assumed to be examples of a specialized craft, unlike the perforated plates. How, then, can we approach this problematic?

Specialization is a complex phenomenon. According to Costin (1991: 4): "Specialization is a differentiated, regularized and permanent production system in which producers depend on extra-household exchange relationships at least in part for their livelihood, and consumers depend on them for acquisition of goods they do not produce themselves". As Costin and others stressed, there are significant differences concerning the organization of production (part or full-time specialist); the products themselves (utilitarian or elite consumption), and the complex set of production networks needed to make a single item. All these hinder an archaeologically-based approximation to identify the existence of specialization in a protohistoric context.

Our proposal is to use an approach that draws on the Cultural Inheritance Theory, also known as the Dual Inheritance Theory (Boyd and Richerson, 1985; Richerson and Boyd, 2010). It is based on the premise that genes and culture provide separate, albeit linked, systems of inheritance, variation and evolutionary change (Shennan, 2002, 2009; O'Brien and Bentley, 2011).

When employing evolution as a means to explain changes in cultural traits, it is important to know how they are transmitted. In fact, as shown in previous works (Eerkens and Lipo, 2005, 2007), the amount of variation expected in a population is heavily dependent on the modes and rules in which information is transmitted. More remarkably is the differential distribution of this variation produced for the same rules between different groups of a population (Shennan, 2009).

Drawing on this theoretical framework, our intention here is to determine whether the combs and perforated plates were the result of specialized craftsmanship, which would imply the concentration of production in fewer hands - and thus an example of oblique transmission - or if both types were subject to different types of transmission and learning processes (oblique vs vertical or horizontal) (Fig. 1).

\begin{tabular}{|c|c|c|c|c|}
\hline \multicolumn{5}{|c|}{ Modes of Cultural Transmission } \\
\hline & $\begin{array}{c}\text { Vertical or } \\
\text { parent-to child } \\
\text { or } \\
\text { ontal }\end{array}$ & $\begin{array}{c}\text { One-to-many } \\
\text { contagious }\end{array}$ & Concerted or many- \\
\hline $\begin{array}{c}\text { Transmitter } \\
\text { Transmittee }\end{array}$ & Parent(s) & Unrelated & Teacher/leader/media & $\begin{array}{c}\text { Older members of } \\
\text { social group }\end{array}$ \\
\hline $\begin{array}{c}\text { Acceptance } \\
\text { of } \\
\text { innovation }\end{array}$ & $\begin{array}{c}\text { Intermediate } \\
\text { difficulty }\end{array}$ & Enrelated & Pupils/citizens/audience & Younger members \\
\hline $\begin{array}{c}\text { Variation } \\
\text { between } \\
\text { individuals } \\
\text { within } \\
\text { population }\end{array}$ & High & Can be high & Easy & Very difficult \\
\hline $\begin{array}{c}\text { Variation } \\
\text { between } \\
\text { groups }\end{array}$ & High & Can be high & Can be high & Smallest \\
\hline $\begin{array}{c}\text { Cultural } \\
\text { evolution }\end{array}$ & Slow & Can be rapid & Most rapid & Most conservative \\
\hline
\end{tabular}

Fig.1. Modes of Cultural Transmission (After Shennan 2002: 50). / Modos de Transmisión Cultural (a partir de Shennan 2002: 50).

In a one-to-one (vertical) transmission mode, variability in production sequences is expected to be high within sites and should be equal to or exceed differences between sites. On the contrary, when oblique transmission is prevalent, we can expect a lower variability within a site but one that can be high between sites, depending on whether transmission occurs only within or also between communities. In this latter case, artefacts would be produced by individuals who learned the techniques not from their parents, but rather from experts within the community (Fig. 1).

Although it is true that oblique transmission is not synonymous with a high degree of specialization (Costin, 2001; Costin and Hagstrum, 1995), the latter (as master / apprentice transmission) can be considered a special case of the former (Hosfield, 2009).

Generally, oblique transmission implies a wider, although diverse, geographical distribution than vertical, because here one production unit supplies many social groups, resulting in a lower variability between sites. This, in turn, depends on whether the learning is community-centered, with few or no movements of artisans around communities, or if they can move within communities. Moreover, in a specialized workshop context, pro- 
ducts can move (via trade or any form of exchange) between more or less distant communities; all these factors would affect the spatial pattern of variability and should be taken into account when evaluating the results.

Although this framework has commonly been used to trace cultural evolution (McClure, 2011), other approaches have focused on analyzing variability during a basic period of time in order to evaluate alternative transmission modes (Coto-Sarmiento et al., 2018). The aim of this paper is similar to the second one: By analyzing the variability of combs and plates, we try to evaluate three different but related questions:

- Are combs and plates the result of different processes of information transmission (oblique vs vertical)?

- Are combs and plates the result of oblique transmission, but with different specialization degrees (community-centered vs master/apprentice)?

- Are combs and plates present in the same or in different interaction networks?

\section{MATERIALS AND METHODS}

\subsection{Studied sample and sites}

As stated above, we examine two kinds of artefacts: combs and plates. Both are a representative sample of manufactured hard animal materials of Iberian society. Moreover, they require specific technical knowledge and tools for their elaboration (Mata-Parreño et al., 2017, 2018; Mora-García, 2018)

Our choice was also influenced by the geographical distribution of these objects and their different raw materials. They share, broadly speaking, the same core area: the southeast of the Iberian Peninsula (Fig. 2). Moreover, they were produced using different raw materials: the former are of exogenous provenance (elephant ivory) and the latter are of local origin (bones from domestic or wild mammals).

The combs are rectangular or trapezoidal plates, with a row of teeth. They are almost always decorated

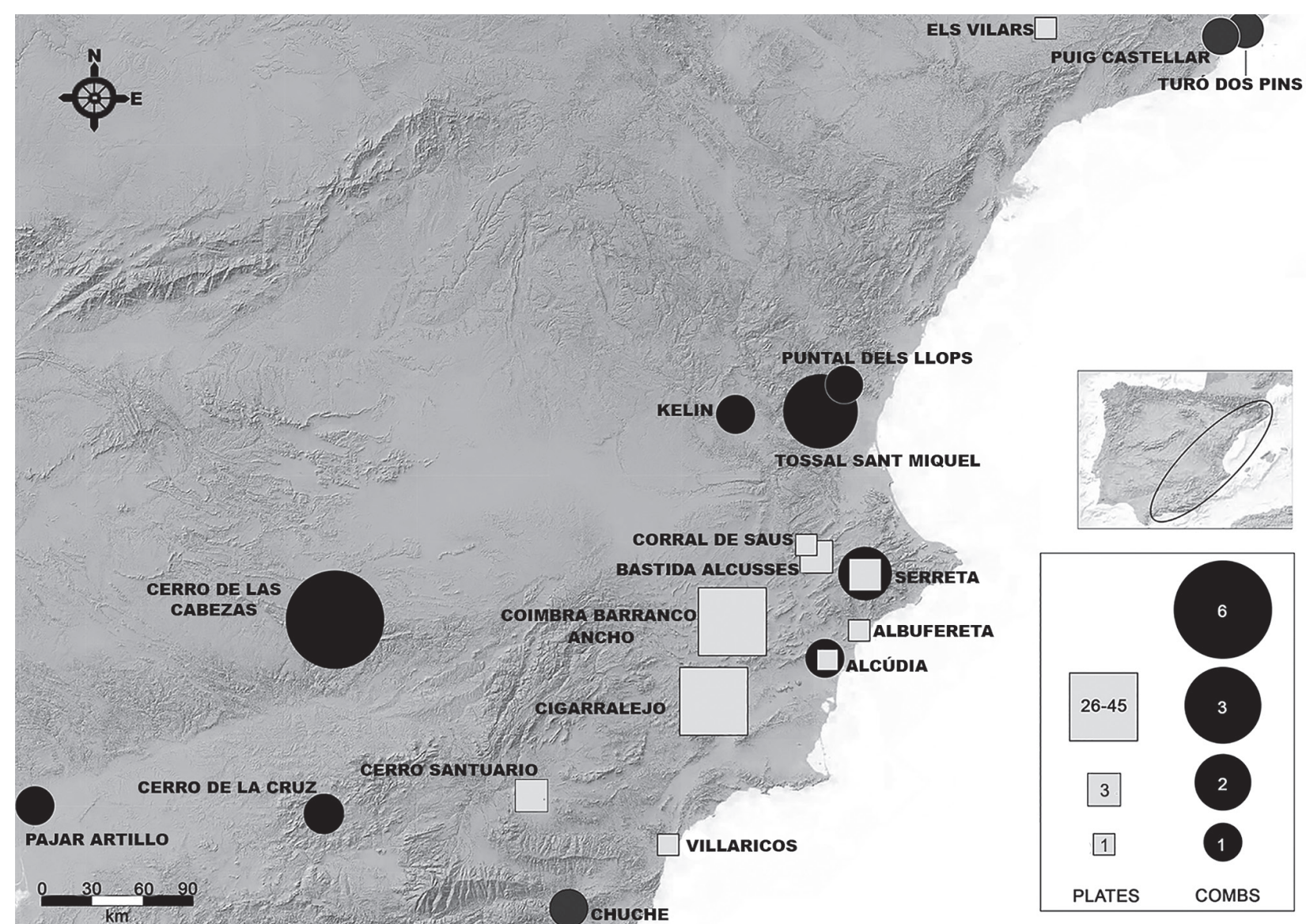

Fig.2. Iron Age sites in Iberian Peninsula with combs and plates. (Map WMTS http://www.ign.es/wmts/mdt). The size of the circles and squares shows the number of pieces in every site. / Yacimientos de época ibérica con peines y placas. (Mapa WMTS http://www.ign.es/wmts/mdt). El tamaño de los círculos y cuadrados muestra el número de piezas en cada yacimiento. Els Vilars (Arbeca, Lleida): Turó dels dos Pins (Cabrera de Mar, Barcelona): Puig Castellar (Santa Coloma de Gramenet, Barcelona); Puntal dels Llops (Olocau, València); Tossal de Sant Miquel (Llíria, València); Kelin (Caudete de las Fuentes, València); La Serreta (Alcoi- Cocentaina- Penáguila, Alicante); Alcúdia (Elx, Alicante); Cerro de las Cabezas (Valdepeñas, Ciudad Real); El Chuche (Benahadux, Almería); Cerro de la Cruz (Almedinilla, Córdoba); Pajar de Artillo (Santiponce, Sevilla); Corral de Saus (Moixent, València); Bastida de les Alcusses (Moixent, València): Albufereta (Alacant); Coimbra del Barranco Ancho (Jumilla, Murcia); El Cigarralejo (Mula, Murcia); Villaricos (Almería); Cerro del Santuario (Baza, Granada). 
by means of incision or carving techniques, with geometrical motifs and vegetal or zoomorphic figures (Fig. 3). They are objects associated with hair care and even beard care. Combs are a minority production between those made on hard animal material. However, they are the most common artefact considering those made on ivory (Blasco Martín, 2020; fig.6.10 and 528-530).
Thus far we have catalogued 19 ivory combs from 11 sites, dated from the end of the third to the beginning of the second century BC (Fig. 2; Table 1) ${ }^{1}$ (Mata-Parreño et al., 2017). The most numerous and best preserved set of ivory combs is from the Cerro de las Cabezas (Valdepeñas, Ciudad Real).

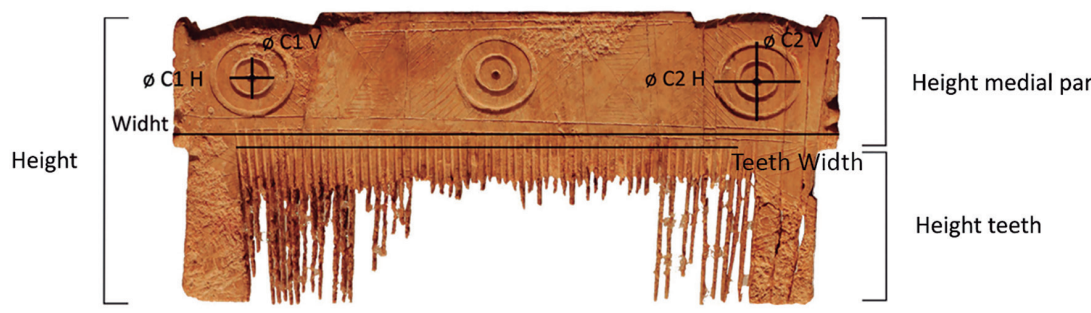

Fig.3. Above: Ivory comb from El Cerro de las Cabezas. Below: Bone plate from El Cigarralejo. Both objects are exhibited as an example of analyzed artefacts, on which we have indicated parts and measures that will be referenced in the methodological part. / Arriba: Peine de marfil de El Cerro de las Cabezas. Abajo: Placa de hueso de El Cigarralejo. Ambos objetos se muestran como ejemplo de los artefactos analizados, sobre ellos se señalan las partes y las medidas empleadas en el análisis metodológico.

\begin{tabular}{|c|c|c|c|c|c|}
\hline Site & $\begin{array}{l}\text { Surface / } \\
\text { Tombs }\end{array}$ & $\begin{array}{l}\text { Artefacts } \\
\text { (num) }\end{array}$ & Context & Chronology & Reference \\
\hline Cerro de las Cabezas (CC) & 14 ha & Combs (6) & Domestic & $3^{\text {rd }}$ century BC & Vélez and Pérez-Avilés, 2008, 2010; Carmona, 2013 \\
\hline Edeta/Tossal de Sant Miquel (TSM) & 10 ha & Combs (3) & Domestic & $3^{\text {rd }}$ century BC & Bonet, 1995 \\
\hline \multirow{2}{*}{ La Serreta (S) } & 5.5 ha & Combs (2) & Domestic & $3^{\text {rd }}$ century BC & Font, 1970 \\
\hline & 75 tombs & Plates (3) & Funerary & $4^{\text {th }}$ century BC & Aura and Segura, 2000 \\
\hline Cerro de la Cruz (CCR) & 5 ha & Combs (1) & Rubbish dump & $3^{\text {rd }}$ century BC & Vaquerizo et al., 2001 \\
\hline El Chuche (CH) & 17 ha & Combs (1) & Domestic & $3^{\text {rd }}$ century BC & Museum of Almeria \\
\hline \multirow{2}{*}{ L’Alcúdia (A) } & \multirow{2}{*}{6 ha } & Combs (1) & Domestic & $3^{\text {rd }}$ century BC? & Ramos, 1956 \\
\hline & & Plates (1) & Domestic & $3^{\text {rd }}$ century BC? & Ramos, 1956 \\
\hline Kelin (K) & 10 ha & Combs (1) & Domestic & $3^{\text {rd }}$ century BC & Mata, 2019 \\
\hline Puntal dels Llops (PLL) & $0.08 \mathrm{ha}$ & Combs (1) & Domestic & $3^{\text {rd }}$ century BC & Bonet and Mata, 2002 \\
\hline Puig Castellar (PC) & 0.4 ha & Combs (1) & Domestic & $3^{\text {rd }}$ century BC & Serra-Ràfols 1942 \\
\hline Pajar de Artillo (PA) & --- & Combs (1) & Domestic & $3^{\text {rd }}$ century BC & Luzón, 1973 \\
\hline Turó dels dos Pins (TDP) & 94 tombs & Combs (1) & Funerary & $3^{\text {rd }}$ century BC & Garcia i Roselló, 1993 \\
\hline El Cigarralejo (EC) & $>500$ tombs & Plates (45) & Funerary & $4^{\text {th }}$ century BC & Cuadrado, 1987 \\
\hline Coimbra del Barranco Ancho (CBA) & 160 tombs & Plates (26) & Funerary & $4^{\text {th }}-3^{\text {rd }}$ century BC & García-Cano 1997, 1999; García-Cano et al. 2008 \\
\hline Cerro Santuario (CS) & $>178$ tombs & Plates (3) & Funerary & $4^{\text {th }}$ century BC & Ruiz de Haro, 2015 \\
\hline La Bastida de les Alcusses (B) & 4.5 ha & Plates (3) & Domestic & $4^{\text {th }}$ century BC & Bonet et al. 2011 \\
\hline Els Vilars (EV) & $0.22 \mathrm{ha}$ & Plates (1) & Domestic & $6^{\text {th }}$ century BC & Junyent and López 2017 \\
\hline Corral de Saus (COS) & 17 tombs & Plates (1) & Funerary & $2^{\text {nd }}$ century $\mathrm{BC}$ & Izquierdo 2000 \\
\hline L'Albufereta (AL) & 267 tombs & Plates (1) & Funerary & $4^{\text {th }}-2^{\text {nd }}$ century BC & Verdú 2015 \\
\hline Villaricos (V) & $>1000$ tombs & Plates (2) & Funerary & $6^{\text {th }}-1^{\text {st }}$ century BC & Siret 1908 \\
\hline
\end{tabular}

Table 1: Information of iberian settlements and necropolis where combs and perforated plates were found. / Información de los yacimientos y necrópolis ibéricas con peines y placas perforadas.

${ }_{1}$ Another ivory comb from El Puig de Sant Andreu (Ullastret) was recovered in excavations during 2018. These excavations are still in process and for that reason we do not consider that comb here. 
The perforated plates are rectangular, flat or slightly concave. They have one to three rows of longitudinal perforations. Most were found in necropolises dated to the fourth century BC. Although we know that the plates were manufactured before (Junyent and López, 2017: 132) and after (Izquierdo, 2000: 241) that time, there are very few known cases (Fig. 2, Table 1). For this reason, in this work we use only those located in fourth and third century BC contexts.

Similar objects have been reported in different chronological contexts as narrow back-strap looms (Leroi-Gourhan, 1943: 236-65). Experimental works show they were uses as small horizontal looms since the Neolithic (Ruano and Montero, 1989; Meneses, 1993: 332; Cardito-Rollán, 1996).

The full sample consists of 84 loom plates from 10 sites (Fig. 2, Table 1), with a significant concentration in two of them: El Cigarralejo (45) and Coimbra del Barranco Ancho (26). Unlike the combs, the vast majority (79) come from mortuary contexts.

\subsection{Morphotechnological analysis and quanti- tative indexes}

As mentioned, to conduct the current study, we draw on the Theory of Cultural Inheritance, applying methods that include both artefact and knowledge. The knowledge base refers to the technological practice: gestures, skills and capacities (McClure, 2011).

To this end, we worked with a series of measures and indices. Some of these refer to public attributes of the artefacts, such as decoration, which is visible and easily subject to processes of social interaction and ho- rizontal transmission. Others, meanwhile, refer to private attributes, that is, those that reflect productive processes and which are not perceptible in the final product. Differentiating between the two types of attributes is key when assessing the distribution of the extant variation. To conduct this work, we examined all the pieces, measuring and photographing the actual artefacts, using a Dino-lite digital microscope. The measures and indices used were:

1) Production Task Index (PTI) which, in both combs and loom plates, relatively measures each decision in the chaîne opératoire that generates a variation in the production cost. The chaîne opératoire approach emphasizes all the steps of the production sequence equally (Lemonnier, 1986; Bleed, 2001). But here we need a useful tool to compare technological complexity between objects. The Production Task Index (PTI) provides us with just such a tool to aggregate chaîne opératoire data into a single value. In practice, the PTI assesses efficiency and labor investment in production tasks (McClure, 2011).

The manufacture of an artefact involves a complex sequencing of a process formed by elementary activities, each with possible alternatives. These are the activities we measured, using different scores, since each of these gestures and their possible alternatives enable us to approach the people and ideas behind the cultural material. First, we developed a general index considering the entire production system for each artefact. We then addressed groups of tasks, differentiating between technological or formal activities related to the decoration and the attributes that possibly correspond to functional needs (Table 2).

\begin{tabular}{|c|c|c|c|}
\hline Combs variables & Valued types and points & Plates variables & Valued types and points \\
\hline Total Area $\left(\mathrm{mm}^{2}\right)$ & $\begin{array}{c}\text { Small }(<3000)=\mathbf{2} \\
\text { Middle }(3000-4000)=\mathbf{3} \\
\text { Big }(>4000)=\mathbf{4}\end{array}$ & End part & $\begin{array}{c}\text { No differentiated }=\mathbf{1} \\
\text { Differentiated }=\mathbf{2}\end{array}$ \\
\hline Teeth Area $\left(\mathrm{mm}^{2}\right)$ & $\begin{array}{l}<1600=1 \\
>1600=2\end{array}$ & Form end part & $\begin{array}{c}\text { Straight }=\mathbf{1} \\
\text { Rounded }=\mathbf{2} \\
\text { Triangular }=\mathbf{2}\end{array}$ \\
\hline Top part moulded & $\begin{array}{l}\text { Yes }=\mathbf{1} \\
\text { No }=\mathbf{0}\end{array}$ & Delineation end part & Serrated $=\mathbf{1}$ \\
\hline Lateral moulded & $\begin{array}{c}\text { Moulding = } \mathbf{1} \\
\text { Simple Relief = } \mathbf{2} \\
\text { Complex Relief = } \mathbf{3}\end{array}$ & Delineation plate & $\begin{array}{c}\text { Straight }=\mathbf{1} \\
\text { Discontinuos =2 }\end{array}$ \\
\hline Decoration top part & $N^{\circ}$ decoration techniques $=\mathbf{0 , 1 , 2}$ & Rows & $\begin{array}{c}\text { One }=\mathbf{1} \\
\text { Two }=\mathbf{2} \\
\text { Three }=\mathbf{3}\end{array}$ \\
\hline Decoration lateral tooth & $\mathrm{N}^{\circ}$ decoration techniques $=\mathbf{0 , 1}$ & Perforation biggest end part & $\begin{array}{l}\mathrm{No}=\mathbf{1} \\
\text { Yes }=\mathbf{2}\end{array}$ \\
\hline Decoration medial Part & $\mathrm{N}^{\circ}$ decoration techniques $=\mathbf{0 , 1 , 2}$ & Decoration & $\begin{array}{c}\text { Incision }=\mathbf{1} \\
\text { Simple circle }=\mathbf{2} \\
\text { Concentric circle }=\mathbf{3}\end{array}$ \\
\hline $\mathrm{N}^{\circ}$ concentric circles & $=0,1,2,3$ & --- & --- \\
\hline
\end{tabular}

Table 2: Variables and point values (in bold) associated with the calculation of Production Task Index (PTI) in combs and plates. / Variables y puntuaciones (en negrita) asociadas al cálculo del Îndice de producción de tareas (PTI) en peines y placas. 
The technological attributes of the combs are Total Area and Teeth Area. The Total Area was used as a proxy for the cost of acquiring the raw material plus the elaboration of the preform we used the total surface of the comb's plaque, in $\mathrm{mm}^{2}$, as a proxy for the acquisition cost, assuming that the larger the size, the higher the cost. Teeth Area represents the work invested in sawing the teeth, which is the most delicate step in the chaîne opératoire, as has been shown in different experimental works (Picod et al., 2016; Mata-Parreño et al., 2018). The shape of the top part of the combs was also taken into account to evaluate the work invested and the decoration was also rated. In addition, the decorative techniques and moulded sides were considered as public attributes, assessed according to the difficulty of design and manufacture (Fig. 3, Table 2).

For the loom plates, the formal attributes considered were the differentiated or non-differentiated end parts, their shape and the delineation of the body. In addition, we considered the decorative techniques and their presence on one or both sides of the object (Table 2). These items are important to estimate the time and effort invested in manufacturing each artefact. As this is the first study including all bone plates that exist in the Iberian Peninsula, we propose a typological classification, considering the variables assessed on the PTI (Mora-García, 2018).

In contrast with PTI, which combines public and private attributes, we also took into account other indices that mainly refers to private attributes.

2) Shape Index (SI) quantifies the general shape of the combs. It is calculated by dividing the height of the comb by the width.

3) Teeth Width (TW) measures the width of the part of the comb occupied by the teeth. We were able to calculate this mainly due to the good state of preservation of the artefacts.

4) Teeth Index ( $\mathrm{TI})$ is the proportion between the height occupied by the teeth and the total height of the comb. In contrast to Teeth Width, this measure does not depend on the size of the piece.

5) Circle Shape Index (CSI) determines the relationship between the horizontal and vertical diameters of the incised circles, as we observed small differences between them. Such differences are either due to the curvature of the piece or to the hand movements used to make the circles. These variations are also found in replicas in experimental works (Mata-Parreño et al., 2018). We always used the measurement of the interior circle, as it was the only one that could be compared across all the pieces with this type of decoration.

6) Overlapping Circle Index $(\mathrm{OCl})$ is the relationship between the maximum diameter of the smallest circle and the next one (Fig. 3). This measure could evidently only be obtained in pieces with two or more concentric circles.
These last two indices (CSI and $\mathrm{OCI}$ ) were developed in order to identify common patterns or disruptive elements in making the circles, given that we believe they may have been made with specific, fixed-diameter tools. Depending on the measures of the tool and the craftspeople's skills, the results are circles with varying degrees of regularity and a greater or lesser separation between the concentric circles.

\section{RESULTS}

All the data obtained were treated taking into account the most numerous sets of artefacts and the most complete objects: Cerro de las Cabezas (CC) for the combs and El Cigarralejo (EC), Coimbra del Barranco Ancho (CBA) and La Serreta (S) for the perforated plates, and comparing them with the overall sample (Table 3). It is worth noting that the sample is very small for some of the sections, especially in the case of the combs. It's important pointing that to compare the variables of our populations, we used the coefficient of variation $(\mathrm{CV})$, which determines the degree of variability between series of frequencies, regardless of the scale used. Given the factors conditioning the available sample, we applied the CV between the sites and the total population (Table 3).

Speaking overall, it can be underlined that the Coeficient of Variation corresponding to each site was always lower than that of the set of artefacts, except for the Production Task Index of plates. These results are within the expected values if the transmission of information is oblique. The variation within each site, however, is clearly higher in the measures comparing absolute values (PTI, TW and SI) than for the indices measuring the proportions of the pieces (CSI, OCl and $\mathrm{TI})$. This aspect is worth commenting upon separately for each of these groups of measurements:

- The variation in the indices related to circles is, with only small differences, practically the same in all the samples. The low and similar $\mathrm{CV}$ in $\mathrm{OCl}$ suggests a high level of standardization in production (Table 3, Fig. 4).

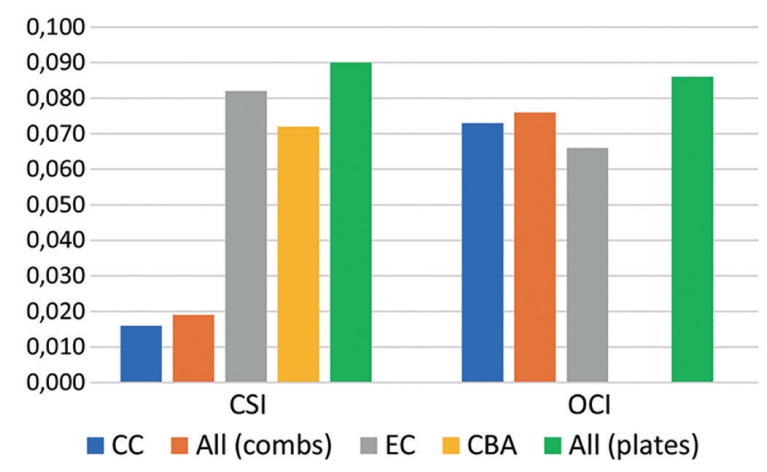

Fig.4. Coefficient of variation of Circle Shape Index (CSI) and Overlapping Circle Index (OCI) in both combs and plates. / Coeficiente de variación del Índice del Área del Círculo (CSI) y del Índice de Solapado de los Círculos $(\mathrm{OCl})$ en peines y placas. 


\begin{tabular}{|c|c|c|c|c|c|c|c|}
\hline & & \multicolumn{2}{|l|}{ COMBS } & \multicolumn{4}{|c|}{ PERFORATED PLATES } \\
\hline & & Cerro de las Cabezas & All sites & El Cigarralejo & Coimbra Barranco Ancho & La Serreta & All sites \\
\hline \multirow{4}{*}{ Circle Shape Index (CSI) } & $\mu$ & 0.951 & 0.958 & 0.855 & 0.952 & 0.892 & 0.885 \\
\hline & $\sigma$ & 0.016 & 0.018 & 0.07 & 0.069 & 0.048 & 0.08 \\
\hline & $N(n)$ & $21(4)$ & $32(7)$ & $76(25)$ & $26(4)$ & 14(3) & 136(35) \\
\hline & $\mathrm{CV}$ & 0.016 & 0.019 & 0.082 & 0.072 & 0.054 & 0.09 \\
\hline \multirow{4}{*}{ Overlaping Circle Index (OCI) } & $\mu$ & 0.555 & 0.557 & 0.621 & & 0.613 & 0.606 \\
\hline & $\sigma$ & 0.029 & 0.034 & 0.041 & & 0.026 & 0.042 \\
\hline & $\mathrm{N}$ & $21(4)$ & $32(7)$ & 20(8) & & $6(1)$ & $29(10)$ \\
\hline & $\mathrm{CV}$ & 0.073 & 0.076 & 0.066 & & 0.042 & 0.086 \\
\hline \multirow{4}{*}{ Shape Index (SI) } & $\mu$ & 0.464 & 0.483 & & & & \\
\hline & $\sigma$ & 0.059 & 0.092 & & & & \\
\hline & $N(n)$ & 4 & 11 & & & & \\
\hline & $\mathrm{CV}$ & 0.127 & 0.19 & & & & \\
\hline \multirow{4}{*}{ Teeth Widht (TW) } & $\mu$ & 72.52 & 73.05 & & & & \\
\hline & $\sigma$ & 5.37 & 11.55 & & & & \\
\hline & $\mathrm{N}$ & 4 & 10 & & & & \\
\hline & $\mathrm{CV}$ & 0.089 & 0.158 & & & & \\
\hline \multirow{4}{*}{ Teeth Index (TI) } & $\mu$ & 0.582 & 0.599 & & & & \\
\hline & $\sigma$ & 0.027 & 0.042 & & & & \\
\hline & $\mathrm{N}$ & 4 & 10 & & & & \\
\hline & $\mathrm{CV}$ & 0.046 & 0.07 & & & & \\
\hline \multirow{5}{*}{ Production Task Index (PTI) } & $\mu$ & 12 & 7.11 & 9.826 & 8.923 & & 9.512 \\
\hline & $\sigma$ & 4.15 & 3.58 & 1.736 & 1.071 & & 1.576 \\
\hline & Range & $4 / 18$ & $6 / 18$ & $7 / 14$ & $7 / 13$ & & $7 / 14$ \\
\hline & $\mathrm{N}$ & 5 & 15 & 23 & 13 & & 43 \\
\hline & $\mathrm{CV}$ & 0.334 & 0.42 & 0.177 & 0.12 & & 0.166 \\
\hline
\end{tabular}

Table 3: General table with results of different measures and indices analyzed. We specify the value of mean $(\mu)$, standard deviation ( $\sigma)$, sample $(N)$, range $(\mathrm{R})$ and coefficient of variation (CV). The circles indices, the number of combs or plates (n) and the number of circles measured (N) is detailed for each case. / Tabla general con los resultados de las diferentes medidas e índices analizados. Especificamos el valor de la media ( $\mu$ ), desviación estándar ( $\sigma)$, muestra $(N)$, rango $(R)$ y coeficiente de variación $(C V)$. En los índices de los círculos, el número de peines o placas (n) y el número de círculos medidos (N) se detalla en cada caso.

It is likely, therefore, that these circles were made with ad hoc designed tools, with a fixed diameter depending on the desired circle or circles. If this is true, examining the dimensions and their regularity might be of interest to delve deeper into the analysis of production between workshops.

- Interestingly, variation in CSI is clearly higher in plates (0.09) than in combs (0.019). This suggests a higher level of specialization in combs and a lower tendency towards innovation, which it is consistent with a master/apprentice scenario.

- In contrast, the PTI of the plates and combs exhibit moderate Coefficient of Variation (from 0.166 to 0.42). This might be the result of both a lower level of standardization and/or the existence of diversified production aimed at markets with different demands and/or needs. Analysis of the distribution of the PTI scores might help determine whether these processes occurred.
- Figure 5 a shows the proportional distribution of PTI scores in combs. Although the sample from Cerro de las Cabezas (CC) is small, it is interesting to notice the distribution of the entire sample, where we find a concentration in its lower part and another in the upper part, suggesting a bimodal trend. If the trend is not the result of the sample size, then the shape of the curve might indicate the presence of different types of production for the combs.

- The values for the PTI of the perforated plates exhibit a different trend to the combs, with a normal distribution (Fig. 5b). Although the overall CV is lower $(<0.2)$ than in the case of the combs, it is high and also shows substantial variations between settlements. This suggests that there are no differences in the type of production between them.

- This notion appears to be corroborated if we consider the correlation between SI and TI, using only those combs with complete information. The resulting 
graph (Fig. 6a) suggests a norm establishing proportions between $>0.4$ y $<0.6$ for the general shape of the comb, while the proportion occupied by the teeth is between $>0.5$ and $<0.7$. Four combs do not follow this norm: K01, PA01, CC04 and CC05. These are generally small, square (K01) or long and narrow (PA01, CC04 and CC05). The rest fall into two groups (CC02, A01 and S02; CC01, CC03, CH01 and S01); those in the first group are somewhat more rectangular with shorter teeth, while in the second group, the combs are less rectangular and the teeth are longer.

A)

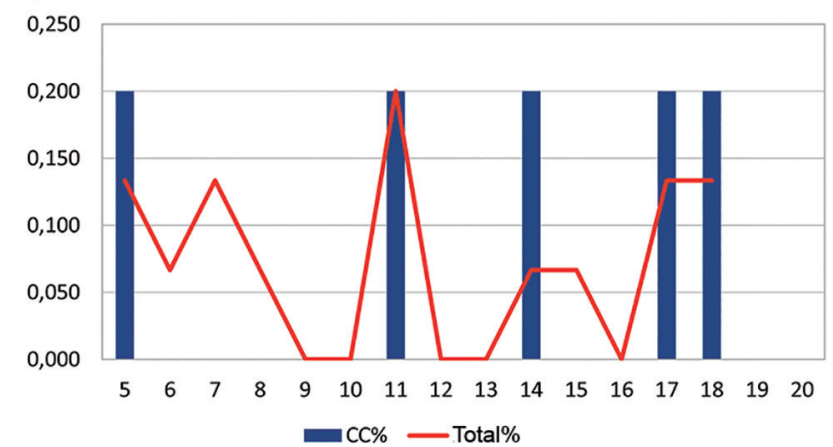

This proportion may be related to the height of the medial part used for decoration (Fig. 6b)

- Moreover, when we distinguish the PTI values according to their public character (those related with decoration) vs private attributes (those related to morphometric character), different patterns emerge (Fig. 7). Variability is greater in combs and plates, but in the latter case do not match with an oblique transmission scenario and shows symptomatic differences between EC, CBA and the total sample (see Discussion).

Fig.5. A) Distribution of PTI scores in combs. B) Distribution of PTI scores in perforated plates (both in percentages). / A) Distribución de las puntuaciones del PTI en los peines. B) Distribución de las puntuaciones del PTI en las placas perforadas (ambas en porcentajes).
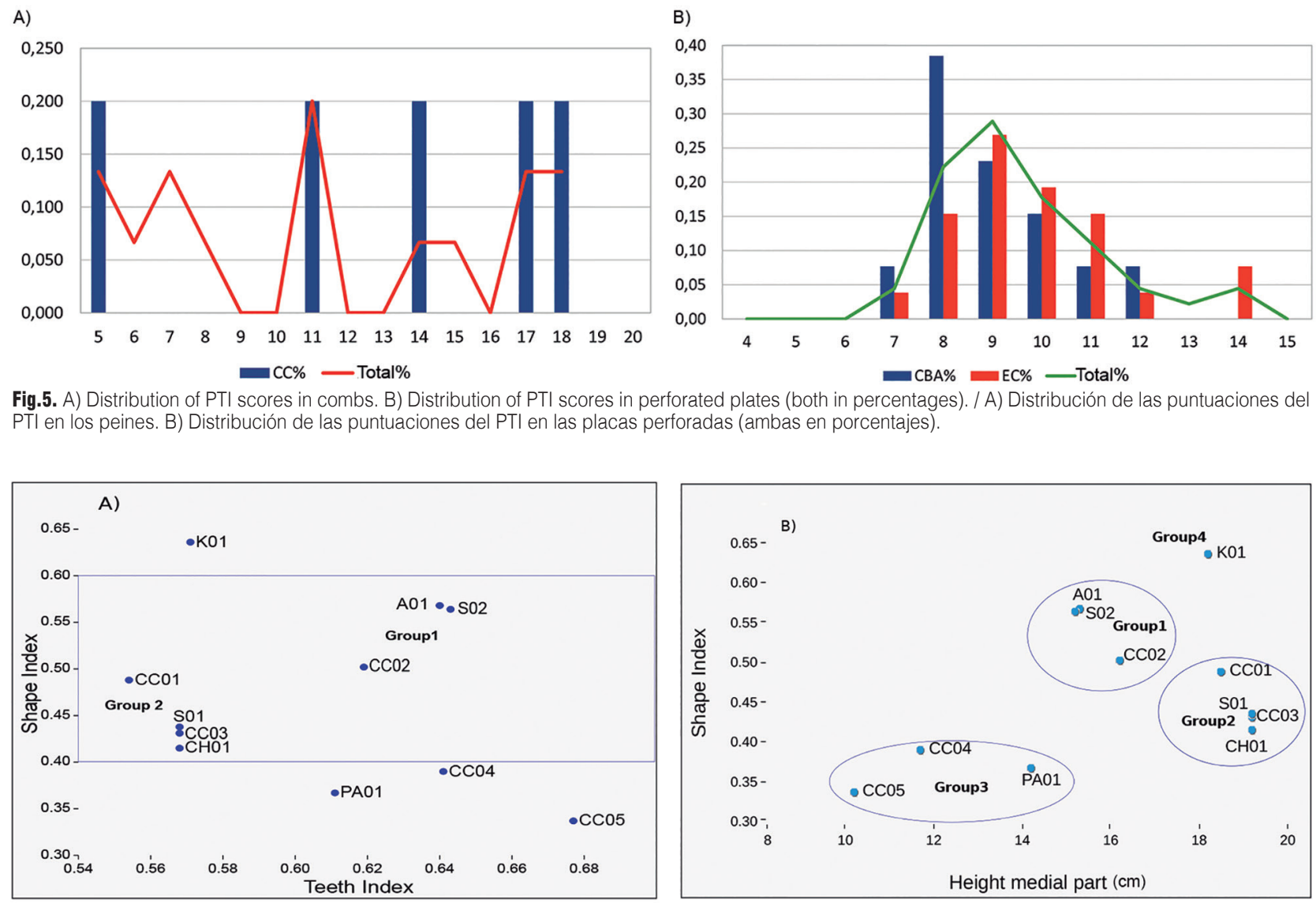

Fig.6. A) Correlation between Shape Index and Teeth Index. B) Correlation and possible groups of combs in accordance with the Shape Index and their Height Medial Part (considering only combs with complete information). / A) Correlación entre el Índice de Forma (SI) y el Índice de Dentado (TI). B) Correlación y posibles grupos de peines según el Índice de Forma (SI) y la altura de la parte medial (Hmp) (considerando solo los peines con la información completa).

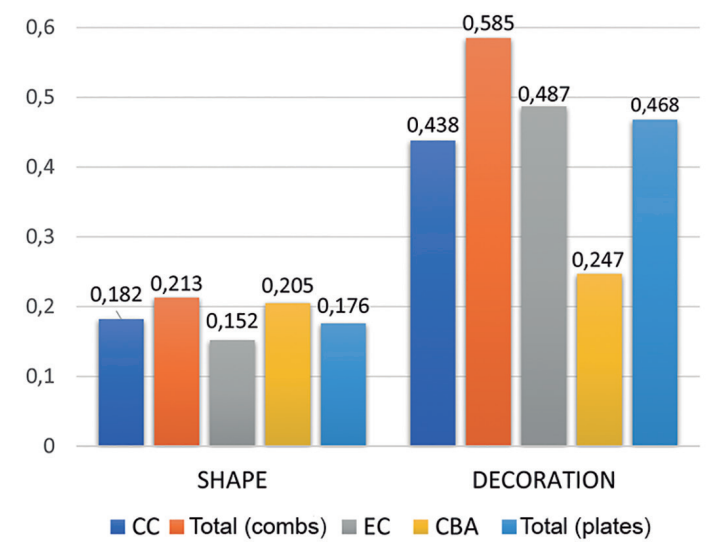

Fig.7. Distribution of scores on values of Shape and Decoration PTI in combs and perforated plates. / Distribución de puntuaciones sobre los valores de Forma y Decoración del PTI en peines y placas perforadas. 


\section{DISCUSSION}

The results lead us to suggest that the manufacture of combs and plates was the subject of oblique transmission. However, both types of artefacts present different qualities suggesting different production and circulation systems.

Regarding the combs, the main criterion that differentiates groups is the relationship between the shape (Shape Index) and the length of the teeth relative to the total length of the comb (Teeth Index). If, in addition, they are related to certain decorative attributes, we can appreciate similarities that suggest the craftspeople who produced them were following a learned work method (Mata-Parreño et al., 2017). The characteristics of the four groups are as follows (Figs. 6 and 8):

Group 1: The combs CC02, A01 and S02 have a moulded top part, complex and moulded sides and geometrical decoration with concentric circles. The Shape Index is between 0.5 and 0.6 and the length of the medial area is between 15 and $17 \mathrm{~mm}$. They present a rectangular shape with short teeth.

Group 2: These combs (CC01, CCO3, $\mathrm{CHO1}$ and S01) have somewhat complex decoration and moulded sides; the top part is either straight or moulded and they also have geometrical decoration and concentric circles. The Shape Index is between 0.4 and 0.5 and the medial area measures between 18 and $19.5 \mathrm{~mm}$. The only exception is S01, which was modified subsequent to manufacture due to a breakage: the top part is carved but lacks circles and has geometric decoration and vegetal figures. These combs are less rectangular and have longer teeth than Group 1.

Group 3: In this group are the more rectangular combs and those with a narrower medial area (CC04,

\section{Group 1}

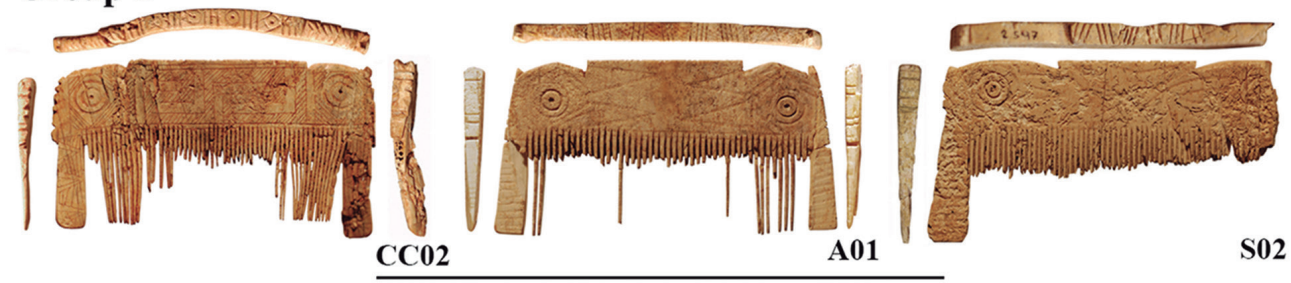

\section{Group 2}

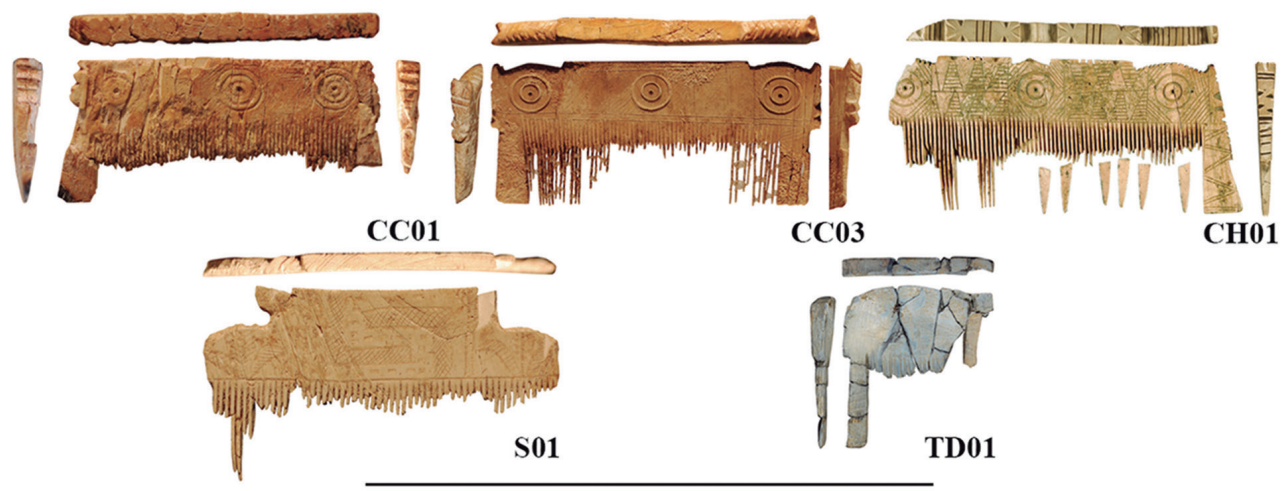

\section{Group 3}
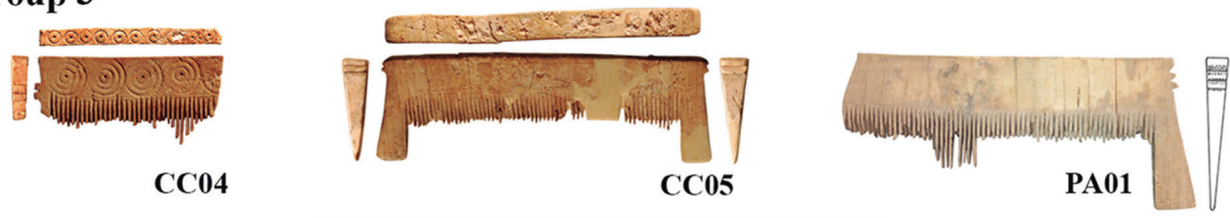

\section{Group 4}
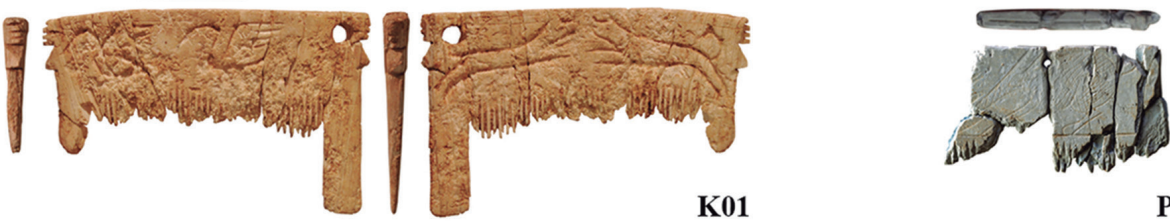

PLL01

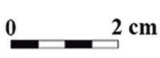

Fig. 8 Groups of combs. Grupos de peines. 
CC05 and PA01). The Shape Index is between 0.34 and 0.47 and the medial area measures between 10 and 14 $\mathrm{mm}$. All three combs have simple moulded laterals, but CCO4 also has circles on the top part and on the medial area, while CC05 and PA01 lack decoration. This suggests that CC05 and PA01 could be unfinished objects because they lack the profuse decoration that characterize these objects.

Group 4: Comb K01 has a very square appearance. It also differs from the rest in its zoomorphic incised decoration, which is different on both sides, and there are no circles. The $\mathrm{SI}$ is 0.64 and the medial area measures $18 \mathrm{~mm}$.

Considering the length of the medial area, almost all the fragmented combs can be assigned to the groups described above. TSM01 (15 mm) and TSM02 (16.9 $\mathrm{mm}$ ) can be included in Group 1, as they both have geometrical motifs and the latter also has a moulded top part with incisions. TD01 (18.5 mm) corresponds to Group 2 as the plate is carved and decorated, the moulded sides are complex and it presents geometrical decoration. CCR01 $(17 \mathrm{~mm})$ can also be assigned to Group 2, given its straight form and its decoration with vegetal and geometrical motifs. Comb PLL01 (17.5 $\mathrm{mm}$ ), which has a straight plate and zoomorphic decoration and lacks circles, can be included in Group 4. Combs TSM03, PC01 and CC06 are too fragmented to reliably attribute them to any group.

Despite the similarity between the different artefacts in Groups 1 and 2, no two combs are exactly the same, leading us to believe that the final product depended on the craftsperson's experience and expertise and, of course, it could depend also on the user's tastes (Mata Parreño et al., 2017). The presence of six combs at Cerro de las Cabezas, with examples belonging to three different groups, suggests the existence of one, or perhaps several, ivory carving craftspeople at the site. La Serreta is another site that might have been home to an ivory work space, given the presence of a modified comb (S01), while the other has what appears to be a mistake or a variation in the concentric circles (S02), and more carved ivory artefacts have been found at the site. The combs from Group 1 and Group 2 are located at distances less than $400 \mathrm{~km}$. From Cerro de las Cabezas and La Serreta, combs might have been exported across great distances, such as Turó dels Dos Pins and Puig Castellar, located over $500 \mathrm{~km}$ from these possible work spaces. The existence of itinerant craftspeople is another possible explanation for the presence at different sites of combs with similar shapes and decorations.

The loom plates also present a model of oblique transmission. With the exception of the indices related to the circles, however, the standardization is not so evident (Table 3). The Productions Task Index values differ greatly between El Cigarralejo and Coimbra del Barranco Ancho, and indeed the CV of the former is higher than that of the overall sample. This suggests a different scenario to that of the combs, where the circulation and exchange of artefacts and/or information was more limited, being confined to the area of immediate influence of each oppidum, possibly due to a simpler work process and an easier access to the raw material (mammal bones) that in the case of the combs.

The typology of these artefacts seems to corroborate this hypothesis. If we consider morphological and decorative criteria, there is greater diversity and less dispersal than among the combs (Fig. 9).

Group 1: This group comprises five pieces (B02, EC06, EC29, CBA4 and S04) from four sites. They have undifferentiated and rounded ends, two or three rows of perforations, a larger orifice at the ends, no decoration, and a PTI score of 8 or 9 . Their simple characteristics suggest they could have been produced by different individuals in each settlement, without necessarily implying an exchange between sites.

Group 2: This group includes EC18, EC23, EC26 and B01. These pieces have a straight, toothed, undifferentiated end, orifices at the ends and three rows of perforations. With the exception of EC18, they are all decorated.

Group 3: This is the most clearly defined group, comprising six plates from Coimbra del Barranco Ancho (CBA01, CBA02, CBA03, CBA04, CBA05, CBA07 and CBA08). They have three slits, two thin ones on either side of a larger one; they have rounded ends, two rows of perforations and a larger orifice at the ends. Only CBA07 is decorated. Taking these characteristics into account, we believe there might have been one or more craftspeople at this site, whose pieces did not spread to other places.

Group 4: In this group there are 10 plates from four sites: El Cigarralejo, La Serreta, L'Alcúdia and Coimbra del Barranco Ancho (EC03, EC07, EC08, EC19, EC20, EC27, EC45, A02, S03 and CBA13), whose only shared attribute is the central, concentric circle decoration. Considering that most of these are from EC, future works will consider more closely the Circle Shape Index and Overlapping Circle Index values, with the aim of identifying the tools used and the possible craftspeople.

In sum, combining the results of $\mathrm{CV}$ values in both public and private attributes, together with typological and decorative patterns described above, we can conclude that although loom plates could be the result of an oblique transmission process, these products do not match with a scenario of master/apprentice like the combs. Despite the proximity between different sites (less than $200 \mathrm{~km}$ ), no identical narrow back-strap looms were found at different sites, suggesting there might have been various craftspeople working at each site, with scant exchange between them; it is also possible, as in the case of combs, that their manufacture or decoration depended on the user's tastes. 


\section{Group 1}
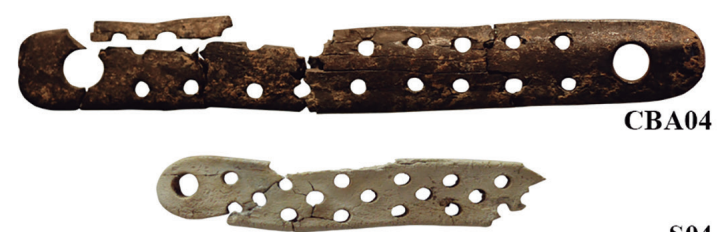

CBA04

S04

Group 2
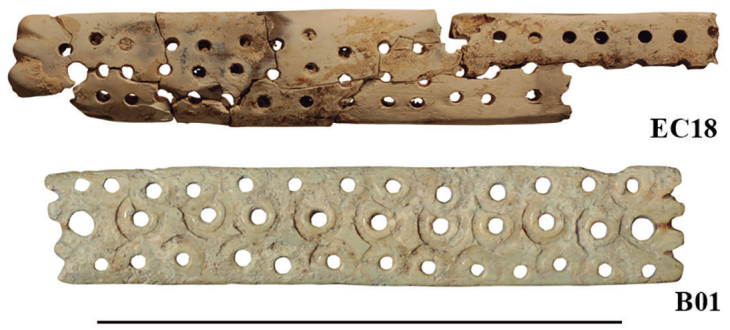

\section{Group 3}

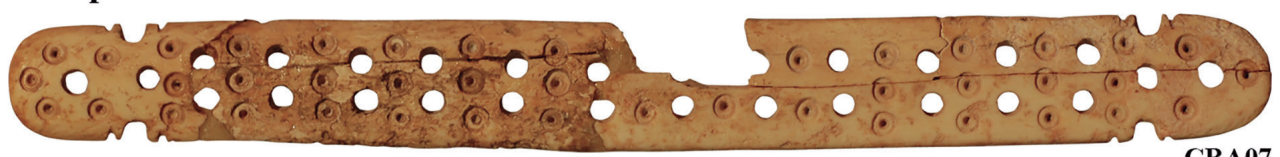

CBA07

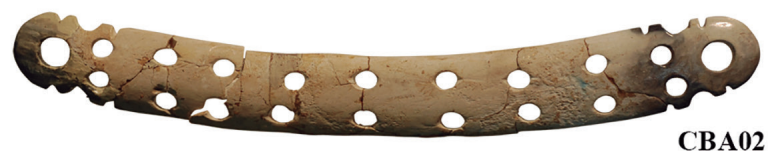

Group 4
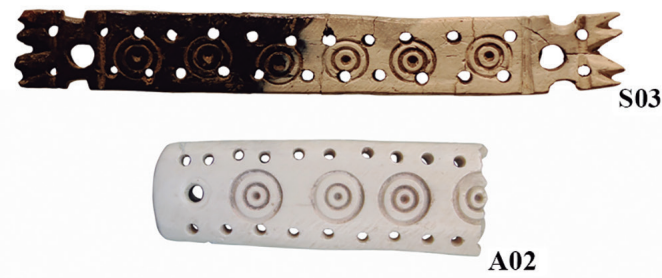

Fig.9. Groups of loom plates. / Grupos de placas de telar.

We must consider that these loom plates do not constitute a majority in the grave goods of the necropoleis. In fact, in El Cigarralejo and Coimbra del Barranco Ancho, loom plates have been recovered in only $5.65 \%$ of the EC tombs (31 cremations) and $11.25 \%$ of CBA tombs (18 cremations).

\section{CONCLUSIONS}

Hard animal material objects from the Iron Age in the Iberian Peninsula have not been studied in depth before the 'Wood, Bone, Ivory, Antler, Shell: Marginal or Marginalized Crafts?' project began in 2014. Its purpose was mainly to advance a typology for these pieces, and also to attempt to understand better the raw materials, manufacture, tools, skills and knowledge transfer involved in their processing. The typology has been developed in extenso by Blasco-Martín (2020) and we have also approached the manufacturing, tools used and artisanal skills to make different items through analyses of ivory combs and handles, perforated plates and bone hairpins (Mata-Parreño et al., 2017, 2018, 2020; Blasco-Martín et al., 2019).
All these works have demonstrated the existence of artisanal works with different degrees of specialization, carried out in different places and social contexts by people with disparate abilities and economic means (access to raw materials and tools). Using an alternative perspective based on the Dual Inheritance Theory and statistical methods (never implemented earlier in research on hard animal materials from Iberian Iron Age), we have attempted to examine more closely the modes of transmission of artisanal knowledge from two items ivory combs and loom plates.

The results obtained allow us to assert that the transmission of knowledge in the manufacture of combs and plates is oblique. We suggest a production focused on a few hands (master/apprentice) in the case of combs, and with more craftspeople - with different degrees of skills and specialization - in the case of loom plates (community-focused). Moreover, the number of combs and loom plates recovered and their geographical distribution also support earlier conclusions, in addition to providing information on the existence of different interaction networks. 
Combs, complicated to manufacture and made with a raw material of difficult access, form part of the family household and are not present in the graves. Consequently, they could be inherited or given as gifts to strengthen alliances, as in the case of ivory-handled knives (Mata-Parreño et al., 2020). The combs present formal and ornamental characteristics in line with indigenous taste and aesthetic, and therefore are products of the Iberian Peninsula. The fact that no two combs are equal suggests that these are custom-made objects.

Ivory carving must have been a discontinuous activity if we take into account the scant number of catalogued pieces, elaborated by craftspeople who undoubtedly worked with other raw materials, such as bone, antler, wood (carpentry) and perhaps precious metals (goldsmithing) or who could share the same specialized areas (multi-crafting loci) (Costin, 2020: 187-188; Mata-Parreño et al. 2017, 2018, 2020; Blasco-Martín et al., 2019). Even though we have not documented scrimshaw workshops, according to data previously considered there may have existed two or three production centers, namely Cerro de las Cabezas, La Serreta (Groups 1 and 2 combs), and a third place without a specific location that produced combs decorated with zoomorphic motifs (Group 4) (Fig. 8).

Conversely, the raw material for the perforated plates was more accessible (bones from medium-sized and large mammals) and involved a simpler production process, thus being a less specialized craft and present in more settlements than the ivory work, as corroborated in several studies (Blasco-Martín, 2015, 2018, 2020). The plates are utilitarian objects mainly distributed throughout the south-eastern peninsula. Their predominant deposition at graves could mean that they were particular/private goods, an idea sustained by the fact that most tombs include just one or two loom plates.

In contrast to the case of ivory, the revised study of the faunal collections from more than forty Iberian settlements has revealed the existence of bone and antler manufacture in most of them. Currently, however, we can only attest a more intense and continuous artisanal work at some settlements, such as Puig de Sant Andreu and Illa d'en Reixac (Ullastret), La Bastida de les Alcusses (Moixent), Covalta (Agres-Albaida) or La Serreta (Alcoi-Cocentaina-Penàguila) (Blasco-Martín, 2020).

Following these promising results, a future line of research might well attempt to assess the scant variability found in the size of concentric circles, in both combs and plates, suggesting the use of the same tools to decorate both types of artefacts. Likewise, it would be necessary to expand the catalogue with a larger number of analyzed objects, since the types of artefacts decorated with circles are limited (hairpins, handles, decorative plates, boxes and perforated discs).

Also, to determine the tools used, it would be necessary to undertake an elaborate, extensive and detailed project of experimentation, with comparison and microscopic analysis of processing marks as has been developed in prehistoric studies (Maigrot, 2003; Sidéra and Legrand, 2006; Baron and Diakoswsky, 2018). We hope to be able to work along this line of research in the near future and to provide more detailed information about handicrafts and craftspeople of hard animal materials in the Iberian Age.

To finish we want to highlight that all the research carried out allows us to affirm that hard animal material manufactures would be a relevant activity in the iberian culture, as well as other craftworks traditionally more studied like metallurgy, goldsmithing or pottery production (Rovira, 1993; Coll, 2000; Quesada et al., 2000; Quixal et al., 2019; between others). Moreover, their study could also reflect works on perishable materials such as wood, other forgotten craftworks that, as Hurcombe points out (2014), should not be ignored from our discourses of the past.

\section{ACKNOWLEDGEMENTS}

This work was supported by the Ministerio de Economia y Competitividad of Spain (HAR2013-45770-P) and the Generalitat Valenciana (ACOMP/2015/256). Marta Blasco-Martín also wishes to acknowledge support from the pre-doctoral grants at the Universitat de València-Atracció del Talent (2016-2020) and at the Instituto Alicantino de Cultura Juan Gil-Albert (2019).

\section{REFERENCES}

Aura, J.E., Segura, J.M. (coords.), 2000. Catálogo Museo Arqueológico Municipal Camilo Viseo Moltó Alcoi. Ajuntament d'Alcoi, Alcoi.

Baron, J., Diakoswsky, M., 2018. Tools make tools: changes in bone and antler manufacture at Late Bronze and Early Iron Age Polish sites. Antiquity 92(363). https://doi.org/10.15184/ aqy.2018.98.

Blasco-Martín, M., 2015. El trabajo sobre hueso, asta y marfil en Covalta. Evidencias de un taller de Época Ibérica. Recerques del Museu d'Alcoi 24, 43-58.

Blasco-Martín, M., 2018. Una visión comparativa. Piezas de hueso, asta y otras materias primas de El Palomar (Oliete, Teruel). In: Agudo, L., Duarte, C., García, A., Geiling, J.M., Higuero, A., Nuñez, F.J. (Eds.), IX Jornadas de Jóvenes en Investigación Arqueológica. Arqueología en 3D: Herramienta social, Agente histórico y Ciencia natural, 139-146, Universidad de Cantabria Press.

Blasco-Martín, M., 2020. Piezas de hueso, asta, cuerno y marfil en época ibérica. De su elaboración a su intepretación. Unpublished PhD dissertation, Universitat de València.

Blasco-Martín, M., Gallello, G., Soria-Combadiera, L., Collado, E., Mata-Parreño, C., 2019. Decoration composition of Iberian Iron Age ivory artifacts identified by non-destructive chemical analysis. Archaeological and Anthropological Sciences 11, 3561-3576. https://doi.org/10.1007/s12520-018-00775-3.

Bleed, P., 2001. Trees or Chains, Links or Branches: Conceptual Alternatives for Consideration of Stone Tool Production and Other Sequential Activities. Journal of Ar- 
chaeological Method and Theory 8, 101-27. https://doi. org/10.1023/A:1009526016167.

Bonet, H., 1995. El Tossal de Sant Miquel de Llíria. La antigua Edeta y su territorio. Diputación de Valencia, València.

Bonet, H., Mata, C., 2002. El Puntal dels Llops. Un fortín edetano. Serie de Trabajos Varios 99. Diputación de Valencia, València.

Bonet, H., Mata-Parreño, C., 2014. Who lives there? Settlements, houses and households in Iberia. In: Knapp, A. B., van DommeIen, P. (Eds.), The Cambridge Prehistory of the Bronze and Iron Age Mediterranean, 471-487, University of Cambridge Press.

Bonet, H., Soria-Combadiera, L., Vives-Ferrándiz, J., 2011. La vida en las casas. Producción doméstica, alimentación, enseres y ocupantes. In: Bonet, H., Vives-Ferrándiz, J. (Eds.), La Bastida de les Alcusses 1928-2010, 139-176, Museu de Prehistòria de València.

Boyd, R., Richerson, P.J., 1985. Culture and the Evolutionary Process. University of Chicago Press, Chicago.

Cardito-Rollán, L.M., 1996. Las manufacturas textiles en la Prehistoria: las placas de telar en el Calcolítico peninsular. Zephyrus XLIX, 125-145.

Carmona, M., 2013. Vida subterránea de un peine de marfil. Extracción y exhibición posterior en el Museo. Orisos 2,151-172.

Coll, J., 2000. Aspectos de tecnología de producción de la cerámica ibérica. III Reunió sobre Economía en el Món Ibèric. SAGVNTVM-PLAV, Extra-3, 191-207.

Costin, C.L., 1991. Craft specialization: issues in defining, documenting and explaining the organization of production. Archaeological Method and Theory 3, 1-56.

Costin, C.L., 2001. Craft production systems. In: Feinman, G.N., Price, T.D. (Eds.), Archaeology at the Millennium: A Sourcebook, 273-327. Kluwer Academic/Plenum, New York. https:// doi.org/10.1007/978-0-387-72611-3_8.

Costin, C.L., 2020. What is a workshop? In: Hodkinson, A.K. Lelek, C. (Eds.), Approaches to the Analysis of Production Activity at Archaeological Sites, 177-197. Archaeopress, Oxford.

Costin, C.L., Hagstrum, M.B., 1995. Standardisation, labour investment, skill and the organization of ceramic production in Late Prehispanic Peru. American Antiquity 60(4), 619-639.

Coto-Sarmiento, M., Rubio-Campillo, X., Remesal-Rodríguez, J., 2018. Identifying social learning between Roman amphorae workshops through morphometric similarity. Journal of Archaeological Science 96, 117-23. https://doi.org/10.1016/j. jas.2018.06.002

Cuadrado, E., 1987. La necrópolis ibérica de "El Cigarralejo" (Mula, Murcia). Bibliotheca Praehistorica Hispana 23, Madrid.

Eerkens, J.W., Lipo, C.P., 2005. Cultural transmission, copying errors, and the generation of variation in material culture in the archaeological record. Journal of Anthropological Archaeology 24, 316-334. https://doi.org/10.1016/j.jaa.2005.08.001.

Eerkens, J.W., Lipo, C.P, 2007. Cultural Transmission Theory and the Archaeological Record: Providing Context to Understanding Variation and Temporal Changes in Material Culture. Journal of Archaeological Research 15, 239-274. https://doi. org/10.1007/s10814-007-9013-z.

Font, M., 1970. Dos peines ibéricos de La Serreta de Alcoy y sus precedentes. Papeles del Laboratorio de Arqueología de Valencia 10, 123-138
García-Cano, J.M., 1997. Las necrópolis ibéricas de Coimbra del Barranco Ancho (Jumilla. Murcia) I. Las excavaciones y estudio analítico de los materiales. Universidad de Murcia, Murcia.

García-Cano, J.M., 1999. Las necrópolis ibéricas de Coimbra del Barranco Ancho (Jumilla, Murcia). II. Análisis de los enterramientos, catálogo de materiales y apéndices antropológico, arqueozoológico y paleobotánico. Universidad de Murcia, Murcia.

García-Cano, J.M., Page, V., Ramos, F., Hernández, E., Gil, F., 2008. El mundo funerario ibérico en el altiplano ibérico en el altiplano Jumilla-Yecla (Murcia): La necrópolis de El Poblado de Coimbra del Barranco Ancho. Investigaciones de 1995-2004. II.-Las incineraciones y los ajuares funerarios. Proyecto Iberos Murcia, Murcia.

Garcia i Roselló, J., 1993. Turó dels Dos Pins. Necròpoli Ibèrica. Museu Comarcal del Maresme, Mataró.

Grau, I., Rueda, C., 2018. La religión en las sociedades iberas: una visión panorámica. Revista de historiografia 28, 47-72. https://doi.org/10.20318/revhisto.2018.4207.

Grau, I., Vives-Ferrándiz, J., 2018. Entre casas y comunidades: Formas de organización y relación social en el área oriental de la península ibérica (Siglos V-II a.n.e.) 73-119. En: Rodríguez, A., Pavón, I., Duque, D. M. (Eds.), Más allá de las casas. Familias, linajes y comunidades en la protohistoria peninsular. Universidad de Extremadura, Cáceres.

Hosfield, R., 2009. Modes of Transmission and Material Patterns in Craft Skills. In: Shennan, S. (Ed.), Pattern and Process in Cultural Evolution, 45-61. Origins of Human Behavior and Culture 2. University of California Press.

Hurcombe, L. M., 2014. Perishable material culture in prehistory: investigating the missing majority. Routledge, London.

Izquierdo, I., 2000. Monumentos funerarios ibéricos: Ios pilares-estela. Serie de Trabajos Varios 98. Diputación de Valencia, València.

Junyent, E., López, J.B. (Coords), 2017. La fortalesa dels Vilars d'Arbeca. Terra, aigua i poder en el món iber. Catàlegs 3, Lleida.

Lemonnier, P. 1986. The Study of Material Culture Today: Toward an Anthropology of Technical Systems. Journal of Anthropological Archaeology 5, 147-86. https://doi. org/10.1016/0278-4165(86)90012-7.

Leroi-Gourhan, A, 1943. L'homme et la matière. Vol. I. Évolution et techniques. Albin Michel, Paris.

Llobregat, E.A., Cortell, E., Moltó, J.J., Segura, J.M., 1992. El urbanismo ibérico en La Serreta. Recerques del Museu d'Alcoi 1, 37-70.

Luzón, J.M., 1973. Excavaciones en Itálica. Estratigrafía en el Pajar del Artillo (Campaña 1970). Excavaciones Arqueológicas en España 78, Madrid.

Maigrot, Y., 2003. Étude technologique et fonctionnelle de l'outillage en matières dures animales. La station 4 de Chalain (Néolithique final, Jura, France). Unpublisehd PhD diserttation, Université de Paris I.

Mata-Parreño, C., 2019. De Kelin a Los Villares (Caudete de las Fuentes, Valencia). Nacimiento y decadencia de una ciudad ibera. Serie de Trabajos Varios 122. Diputación de Valencia, València.

Mata-Parreño, C., Pérez-Jordà, G. (Eds.), 2000. Ibers. Agricultors, artesans i comerciants. III Reunió sobre la Economia en el Món Ibèric. SAGVNTVM Extra-3. Universitat de València. 
Mata-Parreño, C., Soria-Combadiera, L., Blasco-Martín, M., Fuentes-Albero, M., Collado, E., 2017. Peines de marfil y madera de la II Edad del Hierro en la Península ibérica. Talleres, estilos y otros enredos. Complutum 28(1), 141-65. https://doi. org/10.5209/CMPL.58418.

Mata-Parreño, C., Soria-Combadiera, L., Blasco-Martín, M., Fuentes-Albero, M., Fuertes, I., Collado, E., 2018. Raw material, Gestures, Objects. An approach to the work of bone and ivory in the iron age in the Iberian Peninsula. Quaternary International 472A: 115-125. https://doi.org/10.1016/j.quaint.2017.11.045.

Mata-Parreño, C., Soria-Combadiera, L., Blasco-Martín, M., Gallello, G., Belarte, M.C., Pastor, A. 2020. El prestigio de los objetos: mangos de marfil en el mundo ibérico. Zephyrus LXXXVI, 67-86. https://doi.org/10.14201/zephyrus202086.

McClure, S.B., 2011. Learning Technology: Cultural Inheritance and Neolitic Pottery Production in the Alcoi Basin, Alicante, Spain. BAR International Series 2300. Archaeopress, Oxford.

Meneses, M.D., 1993. Reconstrucción técnica, experimentación y estudio comparativo de los "tensadores textiles" de hueso del Neolítico y Calcolítico en Andalucía (España). In: Anderson, P., Beyries, S., Otte, M., Pleisson, H. (Dirs.), Traces et fonctions: les gestes retrouvés, vol. 2, 317-323, Hérault 50.

Mercadal, O. (Coord.), 2005. Món ibèric als Països Catalans. XIII Col·loqui Internacional d'Arqueologia de Puigcerdà: homenatge a Josep Barberà i Farràs. Institut d'Estudis Ceretans.

Mora-García, E., 2018. Placas de hueso perforadas en época ibérica. Una aproximación a su estudio. In: Agudo, L., Duarte, C., García, A., Geiling, J.M., Higuero, A., Nuñez, F.J. (Eds.), IX Jornadas de Jóvenes en Investigación Arqueológica. Arqueología en 3D: Herramienta social, Agente histórico y Ciencia natural, 155-160, Universidad de Cantabria Press.

O’Brien, M.J., Bentley, R.A., 2011. Stimulated Variation and Cascades: Two Processes in the Evolution of Complex.Technological Systems. Journal of Archaeological Method and Theory 18, 309-335. https://doi.org/10.1007/s10816-011-9110-7.

Picod, C., Rodet-Belarbi, I., Châtelet, M., 2016. La fabrication des peignes en bois de cerf et en os de l'Antiquité tardive et du haut Moyen Âge: étude tracéologique et expérimentation sur les peignes d'Obernai et de Marlenheim (Bas-Rhin). Instrumentum 44, 36-45.

Quesada, F., Gabaldón, M., Requena, F., Zamora, M., 2000. ¿Artesanos itinerantes en el mundo ibérico? Sobre técnicas y estilos decorativos, especialistas y terrotio. III Reunió sobre Economía en el Món Ibèric. SAGVNTVM-PLAV, Extra-3, 291-301.

Quixal, D., Mata, C., Serrano, A., 2019. Un edificio de uso artesanal en el poblado ibérico del Pico de los Ajos (Yátova, València). SAGVNTVM-PLAV 51, 261-264.

Ramos, A., 1956. Memoria de las excavaciones practicadas en La Alcudia, Elche (Alicante) (Campañas 1954-1955). Noticiario Arqueológico Hispánico III-IV, Cuadernos 1-3, 102-113.

Richerson, P., Boyd, R., 2010. The Darwinian Theory of Human Cultural Evolution and Gene-Culture Coevolution. In: Bell, M.A., Futuyma, D.J., Eanes, W.F., Levinton, J.S. (Eds.), Evolution since Darwin: The first 150 Years. Sinauer Associates. Gruter Institute Squaw Valley Conference 2010: Law, Institutions \& Human Behavior, Available at SSRN: https://ssrn.com/ abstract $=1616311$.

Rovira, C., 1993. Metal.lúrgia ibèrica: identificació i interpretació dels atuells de reducció i gresols arran de les troballes de 1'Illa d'en Reixac (Ullastret, Baix Empordà). Cypsela X, 61-69.
Ruano, E., Montero, I. 1989. Placas de hueso perforadas procedentes de la necrópolis de El Cigarralejo (Mula, Murcia). Espacio, tiempo y forma, Serie I, Prehistoria y Arqueología 2, 281-302.

Ruiz de Haro, M.I., 2014. Tensadores textiles en la necrópolis de El Cerro del Santuario (Baza, Granada). Bastetania 2, 45-56.

Ruiz-Rodríguez, A., Molinos, M., 1998. The Archaeology of the Iberians. Cambridge University Press, Cambridge.

Serra-Ràfols, J., 1942. El poblamiento de la Maresma o Costa de Levante en la época anterromana. Empúries 4, 69-110.

Shennan, S., 2002. Genes, Memes and Human History. Darwinian Archaeology and Cultural Evolution. Thames and Hudson Press, London.

Shennan, S. (Ed.), 2009. Pattern and Process in Cultural Evolution. Origins of Human Behavior and Culture 2. University of California Press.

Sidéra, I., Legrand, A., 2006. Tracéologie fonctionnelle des matières osseuses: une méthode. Bulletin de la Société Préhistorique Française 2, 291-304.

Siret, L., 1908. Villaricos y Herrerías: antigüedades púnicas, romanas, visigóticas y árabes: memoria descriptiva e histórica. Establecimiento tipográfico de Jaime Ratés, Madrid.

Vaquerizo, D., Quesada, F., Murillo, J.F., 2001. Protohistoria y romanización en la subbética cordobesa. Una aproximación al desarrollo de la Cultura Ibérica en el sur de la actual provincia de Córdoba. Monografías 11, Sevilla.

Vélez, J., Pérez-Avilés, J., 2008. Un espacio de culto del siglo $\checkmark$ en el Cerro de las Cabezas (Valdepeñas, Ciudad Real). In: Jiménez, J. (Coord.), SIDEREUM ANA I: El río Guadiana en época post-orientalizante, 37-60. Instituto de Arqueología de Mérida, Mérida.

Vélez, J., Pérez-Avilés, J., 2010. El oppidum ibérico del Cero de las Cabezas. Estructuras de culto (Valdepeñas, Ciudad Real). In: Tortosa, T., Celestino, S., Cazorla, R. (Coords.), Debate en torno a la religiosidad protohistórica, 21-36. Instituto de Arqueología de Mérida, Mérida.

Verdú, E., 2015. La necrópolis ibérica de L'Albufereta (Alacant). Ritos y usos funerarios en un contexto de interacción cultural. Museo Arqueológico de Alicante, Alicante. 